Syntax Fusion : Jurnal Nasional Indonesia

p-ISSN: $x x x-x x x x$

e-ISSN : $x x x x-x x x x$

Vol. 1, No. 1, Oktober 2020

\title{
PENERAPAN MODEL PEMBELAJARAN COOPERATIVE LEARNING TIPE JIGSAW DALAM MENINGKATKAN MINAT DAN HASIL BELAJAR SISWA KELAS IX F SMP N 1 CANGKUANG, KABUPATEN BANDUNG
}

\section{Drajat}

\section{SMPN 01 Cangkuang, Kabupaten Bandung}

E-mail: Saunggeulis2020@gmail.com

\section{Abstrak}

Metode Jigsaw pada hakekatnya ialah sebuah model pembelajaran yang diutamakan kepada siswa, karena Peran guru sangatlah penting sebagai fasilitator. Tujuan dengan menggunakan metode ini yaitu untuk mengembangkan kerja sama tim, dan keterampilan belajar serta penguasaan pengetahuan yang mendalam secara pendidikan dengan ketidak mungkinan diperoleh siswa apabila dipelajari secara individual. Metode Jigsaw ini cocok dalam meningkatkan tujuan dan pencapaian pengajar dalam kontribusi terhadap pemahaman siswa. Sehingga siswa dapat melakukan pembelajaran dan sesekali dapat mengajarkannya kepada rekan -rekan sesama kelompok. Tidak selamanya di dalam sebuah proses ini, berjalan dengan lancar. Karena tedapat proses penghambatan yang muncul secara seketika dengan seringnya terjadi ketidak terbiasaan siswa terhadap model ini. Pengajar maupun peserta didik masih mengalami dengan terbiasanya menggunakan metode konvesional, diantaranya dengan memberikan materi secara satu arah. Adapun penghambat yang sering terjadi yaitu dengan kekurangannya waktu yang mengakibatkan proses ini menjadi lebih lama dari biasanya, sementara itu waktu yang dilaksanakan harus menyesuaikan dengan beban kurikulum yang disetujui. Bagi guru dalam memperhatikan metode ini harus lebih banyak memerlukan kemampuan lebih untuk menangani situasi dan penanganan yang berbeda. Pada Penelitian Tindakan Kelas (PTK) yang penulis lakukan ini ternyata terbukti bermanfaat untuk menjawab pertanyaan; Apakah melalui model pembelajaran cooperative learning tipe Jigsaw dapat meningkatkan hasil belajar siswa kelas IX F SMP Negeri 1 Cangkuang, Kabupaten Bandung pada materi Barisan dan Deret? Bagaimanakah minat belajar siswa kelas IX F SMP Negeri 1 Cangkuang, Kabupaten Bandung di dalam diskusi kelompok tentang materi Barisan dan Deret melalui model pembelajaran cooperative learning tipe Jigsaw? Ternyata hasilnya memuaskan.

Kata Kunci : Minat Belajar; Hasil Belajar; Cooperative Learning; Jigsaw 
Drajat

\section{Pendahuluan}

Pendidikan merupakan suatu proses dinamis dan berkelanjutan untuk memenuhi kebutuhan siswa dan guru sesuai dengan minat mereka masing-masing, pendidikan juga memiliki tanggung jawab memperluas dan mengembangkan wawasan keilmuan dan membantu mereka agar mampu menjawab tantangan dan gagasan baru untuk kelangsungan masa depannya.

Peran dan fungsi guru sangat penting dalam proses belajar mengajar. Oleh karena itu situasi yang dihadapi guru dalam melaksanakan pengajaran mempunyai pengaruh besar terhadap proses belajar mengajar itu sendiri. Dengan demikian guru seharusnya mengetahui dengan berbagai situasi yang dihadapi. Salah satu kemampuan dasar yang harus dimilki guru adalah merencanakan dan melaksanakan proses belajar mengajar yang efektif.

Dengan mata pelajaran matematika, peserta didik perlu diberikan dengan memulainya dari sekolah dasar dalam menerima suatu pikiran secara logis, analitis, sistematis, kritis dan kreatif serta kemampuan dalam bekerja sama. Bila dalam proses belajar mengajar interaksi guru dan siswa masih satu arah, maka besar kemungkinan pembelajaran tidak efektif dan mengakibatkan siswa sulit menangkap materi, bahkan dapat mengakibatkan siswa mengalami masa kejenuhan.

Oleh karena itu dalam mengajarkan pelajaran matematika, guru hendaknya lebih memilih dengan berbagai variasi pendekatan, mulai dari proses strateginya, situasi metode yang sesuai sehingga bertujuan kepada pembelajaran yang telah direncanakan agar tercapai. Hal ini, selain untuk tercapainya tujuan pembelajaran, juga agar siswa antusias dan memiliki minat (interest) dan rasa penasaran (curiousity) yang tinggi. Minat dan rasa penasaran ini penting agar siswa pantang menyerah, selalu mau berkembang, serta dapat memanfaatkan atau mengaplikaskan apa yang dia pelajari dalam kehidupan sehari-hari.

Untuk mencapai hal tersebut maka diperlukan suatu metode belajar yang sesuai dengan keinginan siswa agar siswa lebih termotivasi dalam belajar matematika. Salah satu metode belajar yang dianggap bisa meningkatkan motivasi belajar siswa yaitu model belajar cooperative learning tipe Jigsaw.

Pembelajaran kooperatif tipe Jigsaw adalah suatu metode pembelajaran yang terdiri dari beberapa banyaknya anggota dalam sebuah kelompok yang menghasilkan dari penguasaan dibagian materi pembelajar dan mampu mengajarkan suatu materi kepada anggota lain dalam kelompoknya (Arends, 1997).

Metode kooperatif pembelajaran tipe Jigsaw merupakan metode pembelajaran yang dimana siswa dapat melakukan pembelajaran dalam sebuah kelmpok yang terdiri dari 4 atau 6 orang dan bekerja sama dengan saling ketergantungan yang membuahkan hasil positif dan ketanggung jawabannya atas sebuah hasil dalam penyelesaian pembelajaran dan menyampaikan materi tersebut kepada anggota kelompok yang lain (Arends, 1997). 


\section{Metode Penelitian}

Pandangan tradisional melihat belajar sebagai salah satu upaya untuk memilih sejumlah ilmu pengetahuan. Sementara dalam pandangan modern, belajar lebih berorientasi pada perilaku dalam merubah secara menyeluruh dan terintegrasi yang mencakup aspek kognitif, afektif dan psikomotor. Adapun yang dimaksud dengan lingkungan mencakup keluarga, sekolah dan masyarakat dimana peserta didik berada (Hanafiah \& Suhana, 2009).

Slavin (2000) mengemukakan bahwa perubahan dalam suatu pembelajaran yang relatif permanen adalah suatu hasil dari proses pengalaman dengan sebuah latihan yang diperkuat. pembelajaran ini merupakan suatu akibat dari adanya sebuah capaian interaksi dan respon. Dinggapnya seseorang dengan melakukan pembelajaran ditunjukkan dapat merubah suatu perilaku.

Dari beberapa pernyataan dapat disimpulkan bahwa belajar ialah sebuah tuntutan seseorang untuk merubah ke perilaku ke arah yang lebih baik secara pengetahuan, sikap maupun keterampilan sebagai hasil dari interaksi dengan lingkungannya sehingga mencakup kesiapan diri, keinginan dan tujuan yang ingin dicapai.

Sementara itu dari beberapa hasil belajar yang mempunyai tolak ukur dapat digunakan dengan menentukan tingkatan keberhasilan dalam mengetahui serta memahami materi pembelajaran. Hasil prolehan pembelajar dapat berupa sebuah seni ataupun keterampilan, nilai serta sikap kepada siswa setelah mengalami beberapa proses belajar. Melalui proses belajar ini, pengajar berharap bahwa siswa dapat memperoleh kecakapan tertentu serta kepandaiannya dalam melakukan perubahan-perubahan pada dirinya.

Menurut (Sudjana, 2009), hasil belajar siswa hakikatnya berupa bentuk dalam proses perubahan dengan melakukan pengertian yang lebih luas mencakup bidang kognitif, afektif dan psikomotorik.

Rahmat Abidin (2004) mengatakan dalam proses pembelajaran yang digunakan dengan hasil dari sebuah proses tes atau pada prosedur penilaian yang sesuai dengan aturan-aturan tertentu, dengan kata lain untuk memiliki hasil daya ingat yang diberikan untuk menguasai materi pembelajaran kepada siswa.

Untuk mendapatkan keberhasilan dalam pencapaian tujuan pembelajaran maka peran guru sangatlah penting dalam menyusun Rencana Pelaksanaan Pembelajaran (RPP) terutama dalam menentukan strategi pembelajaran yang tepat dan berupaya untuk memperoleh suasana belajar mengajar yang menyenangkan sehingga tercapai dengan tujuan pembelajaran dan tingkat keberhasilan dalam mengetahui serta memahami materi pelajaran lebih baik.

Strategi dan model pembelajaran ini merupakan sebuah usaha dalam memperoleh suatu metode untuk mencapai sebuah tujuan dengan menggunakan metode dan proses pemanfaatan dari berbagai sumber daya atau kekuatan dalam mencapai tujuan pembelajaran tertentu. Dalam hal ini pembelajaran cooperatif adalah salah satu solusi yang dapat dilakukan dan dilaksanakan.

Pembelajaran kooperatif merupakan salah satu yang digunakan siswa untuk belajar dan bekerja bersama sama dalam kelompok dan berkolaborasi dengan memiliki anggota yang terdiri dari beberapa orang dengan struktur kelompok yang bersifat heterogen (Huda, 2013) 
Menurut Nurulhayati dalam buku Model-model Pembelajaran (Rusman, 2011) pembelajaran dengan sifat kooperatif merupakan salah satu strategi pendidikan dengan melibatkan kelompok kecil yang saling berinteraksi. Dalam melakukan model ini, siswa dituntut untuk memiliki tanggung jawab, yaitu mereka yang melakukan pendidikan serta pembelajaran untuk diri pribadi dengan membantu sesama aggota kelompok agar terus berusaha dalam belajar.

\section{Hasil dan Pembahasan}

Pada siklus 1, peneliti memberikan tindakan kelas dengan menggunakan model pembelajaran tradsional. Model ini membuat guru sebagai pusat informasi dan sumber bahan ajar utama yang tentunya menggunakan komunikasi satu arah berupa ceramah terhadap siswa. Pada model pembelajaran ini, didapatkan hasil bahwa hampir 56\% siswa tidak memenuhi standar kriteria ketuntasan belajar karena nilainya dibawah KKM (kriteria ketuntasan minimal) seperti yang digambarkan dalam gambar 4.1 berikut:

\section{Gambar 4.1}

\section{Hasil belajar model pembelajaran tradsional berdasarkan KKM}

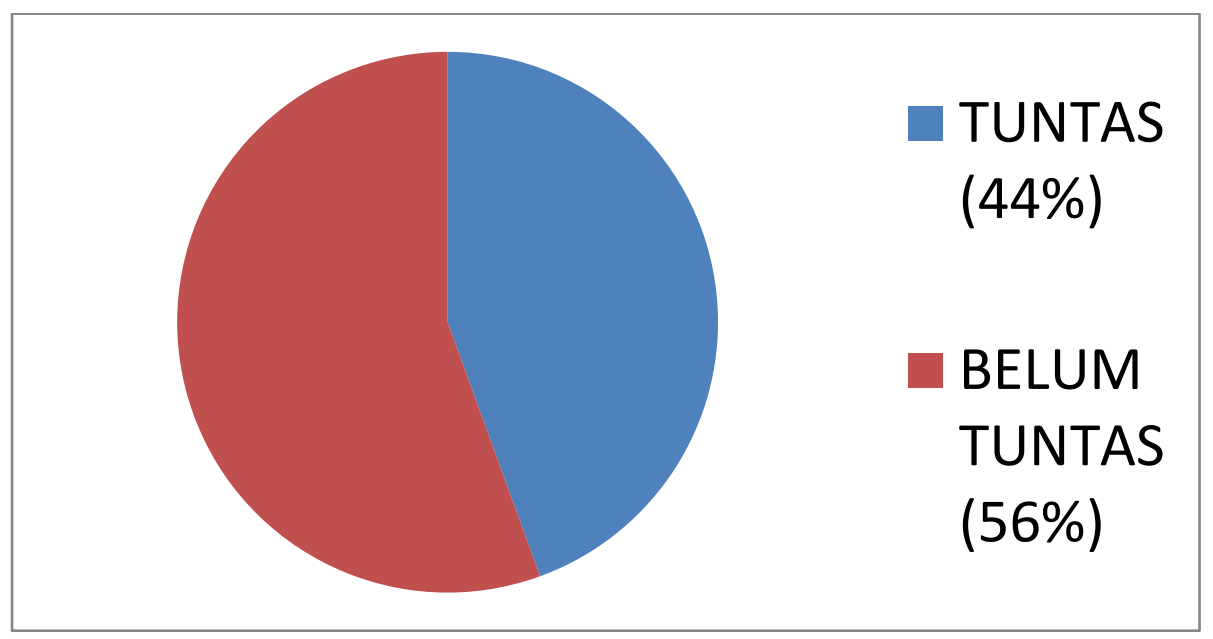

Gambar 4.1 di atas menunjukkan bahwa salah satu yang menggunakan model pembelajaran tradisional, secara deskriptif hanya $44 \%$ siswa yang hasil belajarnya di atas kriteria ketuntasan minimal. Artinya bahwa kurang dari setengah partisipan memahami materi yang diberikan.

Temuan ini dirasa wajar karena bentuk komunikasi yang diterapkan dalam pembelajaran tradisional masih satu arah, sehingga besar kemungkinan anak menjadi segan untuk bertanya bila tidak mengerti, atau takut dianggap bodoh bila bertanya. Berbeda dengan model pembelajaran kooperatif jenis Jigsaw yang diterapkan pada siklus 2 , didapatkan kemajuan pembelajaran yang signifikan. Seperti yang dapat dilihat dari gambar 4.2 berikut: 
Gambar 4.2

\section{Hasil belajar model pembelajaran kooperatf jenis Jigsaw berdasarkan KKM}

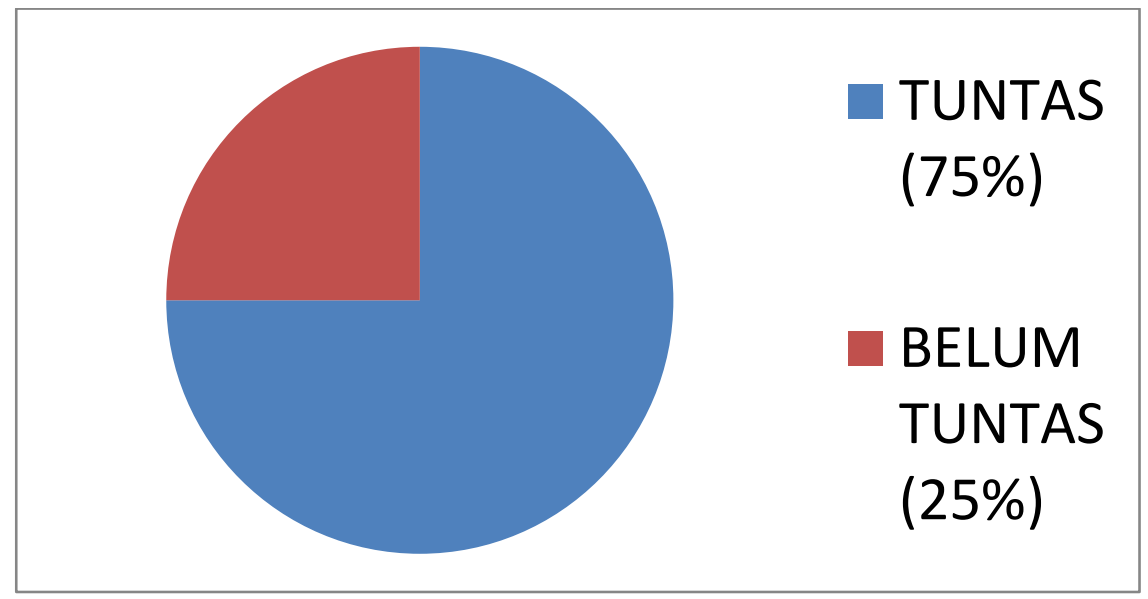

Melalui gambar 4.2 di atas dapat disimpulkan bahwa sebagian besar (75\%) siswa dapat memenuhi kriteria minimal untuk memahami materi yang disampaikan. Hal ini tentu sesuai prediksi karena pembelajaran kooperatif jenis Jigsaw adalah satu jenis pembelajaran yang terdiri dari beberapa anggota di dalam suatu kelompok yang bertanggung jawab atas materi pembelajaran yang dikuasai dan dapat mengajarkan bagian kepada anggota lain. Jigsaw mendesign untuk meningkatkan rasa tanggung jawab dalam sebuah pembelajaran sendiri maupun pembelajaran orang lain.

Untuk menguji hipotesis pada penelitian ini, kedua hasil belajar pada model pembelajaran yang berbeda dibandingkan menggunakan uji statistik dependent t-test dengan bantuan software statistik SPSS for windows. Berikut hasil perhitungan uji dua beda hasil model pembelajaran tradisional dengan pembelajaran kooperatif jenis Jigsaw.

Tabel 4.1

Perbandingan Model Pembelajaran tradisional dengan Pembelajaran Kooperatif Jenis Jigsaw

\begin{tabular}{|c|c|c|c|c|c|c|c|}
\hline \multicolumn{5}{|c|}{ Paired Differences } & \multirow{3}{*}{$\mathrm{t}$} & \multirow{3}{*}{ df } & \multirow{3}{*}{$\begin{array}{l}\text { Sig. (2- } \\
\text { tailed) }\end{array}$} \\
\hline \multirow[t]{2}{*}{ Mean } & \multirow[t]{2}{*}{$\begin{array}{c}\text { Std. } \\
\text { Deviation }\end{array}$} & \multirow[t]{2}{*}{$\begin{array}{c}\text { Std. Error } \\
\text { Mean }\end{array}$} & \multicolumn{2}{|c|}{$\begin{array}{l}\text { 95\% Confidence } \\
\text { Interval of the } \\
\text { Difference }\end{array}$} & & & \\
\hline & & & Lower & Upper & & & \\
\hline-8.05556 & 6.12696 & 1.02116 & -10.12862 & -5.98249 & -7.889 & 35 & .000 \\
\hline
\end{tabular}

Berdasarkan tabel 4.1 di atas hasil belajar dengan model pembelajaran kooperatif jenis Jigsaw $(M=75,41, S D=6,58)$ lebih tinggi secara signifikan dibandingkan dengan 
model pembelajaran tradisional $(M=67,36, S D=10,72), \mathrm{p}=0,000$. Hasil perhitungan ini menunjukkan bahwa model pembelajaran kooperatif jenis Jigsaw mampu untuk lebih meningkatkan hasil pembelajaran kepada siswa secara signifikan dibanding model pembelajaran tradisional.

Model Jigsaw pada hakekatnya adalah suatu pembelajaran kooperatif yang yyang berpusat dan bertujuan langsung kepada siswa. Disini siswa mempunyai peran serta tanggung jawab yang besar dalam pembelajaran karena guru pada hakekatnya ialah yang berperan sebagai fasilitator dan motifator. Tujuan dalam metode yang diberikan Jigsaw adalah antara lain mengembangkan situasi kerja tim, dengan keterampilan belajar kooperatif serta dapat menguasai pengetahuan secara mendalam dengan hal yang tidak mungkin didapat oleh siswa apabila mempelajarinya satu materi dengan individual.

Dari hasil lembar rekaman observasi, dapat dilihat bahwa indikator-indikator kemunculan perilaku yang menunjukkan minat dan antusiasme belajar meningkat secara signifikan. Hal ini besar kemungkinan disebabkan oleh model pembelajaran kooperatif jenis Jigsaw merangsang anak untuk aktif, partisipatif, dan menghilangkan rasa canggung karena para siswa berhadapan dengan siswa juga. Membuat suasana sharing dan transfer pengetahuan lebih terasa mendalam dan menyenangkan.

Pembelajaran metode Jigsaw, setiap siswa dituntut untuk bertanggung jawab atas segala ketuntasannya dalam apa yang dipelajari dan dapat menyampaikan materi yang diterima kepada anggota kelompok lain.

Melalui dua siklus tindakan kelas dengan model pembelajaran yang berbeda, peneliti menemukan beberapa kelebihan dari model pembelajaran kooperatif jenis Jigsaw. Pembelajaran kooperatif jenis Jigsaw dalam penelitian ini dapat memacu para siswa agar lebih mengedepankan ke kreatifitasan serta aktif terhadap suatu pembelajaran. Mendorong agar para siswa terus berfikir kritis dan memberikan suatu kesempatan kepada setiap jajaran siswa untuk menerapkan ide yang dimiliki untuk selanjutnya dapat menjelaskan sebuah materi yang dipelajarinya kepada siswa lain atau suatu kelompok belajar yang tersebut. Dan menerapkan sistem diskusi yang tidak didominasi oleh salahsatu siswa saja, melainkan kepada seluruh siswa bahkan guru sekalipun untuk menjadi aktif dalam berdiskusi.

\section{Simpulan}

Metode Jigsaw pada hakikatnya ialah sebuah model pembelajaran yang berpusat dan bertujuan kepada siswa. Dan seorang siswa mempunyai peran serta tanggung jawab yang besar dalam mengikuti sebuah pembelajaran kooperatif. Dengan mencapai sebuah tujuan dan pengembangan tim, serta keterampilan belajar dan penguasaan ilmu pengetahuan secara mendalam yang tidak dapat diperoleh siswa mengenai pembelajaran dengan materi secara individual. pencapaian tujuan pengajaran dan berkontribusi terhadap pemahaman siswa. Sehingga siswa dapat belajar dengan mengejar sebuah konten kepada rekan satu kelompok kecil.

Tidak selamanya proses pembelajaran dengan metode Jigsaw ini berjalan dengan normal, karena terdapat beberapa hambatan yang muncul yaitu seringnya terjadi 
kekurangan peserta didik dalam kebiasaan mengajar dengan metode Jigsaw. Pengajar dengan peserta didik yang masih terbiasa dengan suasana metode konvesional, dimana dengan pemberian materi hanya satu arah.

Faktor penghambat dari semua materi adalah persoalan waktu, karena metode ini membutuhkan waktu yang lebih banyak dan pelaksanaannyapun harus di sesuaikan dengan beban kurikulum. Kegiatan mengajar ini sangat membutuhkan waktu daripada model pendidikan yang lain, karena bagi guru hakikatnya adalah menemukan dan memerlukan kemampuan siswa yang lebih banyak dalam penanganan yang berbeda.

\section{Bibliografi}

Abdin, Zainal. 2004. Evaluasi Pengajaran. Padang: UNP Press

Arends, R. (1997). Classroom instruction and management. McGraw-Hill Companies.

Hanafiah, N., \& Suhana, C. (2009). Konsep strategi pembelajaran. Bandung: Refika Aditama.

Huda, M. (2013). Model-model pengajaran dan pembelajaran. Yogyakarta: Pustaka Pelajar, 265.

Huda, Miftahul. 2015. Cooeperative Learning. Yohyakata: Pustaka Pelajar

Jing Meng.2010. Jigsaw Cooperative Learning in English Reading. ISSN 1798-4769

Journal of Language Teaching and Research, Vol. 1, No. 4, pp. 501-504, July 2010

Jazuli.2009. Jigsaw tye of cooperative learning as means of improving high schoolstudents'mathematical communication ability. International Journal for Education Studies, I(2) 2009

Joseph.N. Payne (1993). Matematics for the Young Child. Virginia : Teacher of Matematics INC

Rusman. (2013). Model-model Pembelajaran. Jakarta: Rajawali Pers.

Rusman. (2011). Model-model pembelajaran: Mengembangkan profesionalisme guru.

Rajawali Pers/PT Raja Grafindo Persada.

Robert E. Slavin. 2000. Educational Psychology: Theory and Practice.Pearson Education. New Jersey.

Suroto.2012. Pembelajaran Matematika Model Kooperatif Tipe Jigsaw pada Materi Prisma dan Limas Kelas VIII. ISSN 2252-6404 Journal of Primary Education1 (1) (2012)

Sudjana, N. (2009). Penilaian hasil belajar proses belajar mengajar. Bandung: PT

Remaja Rosdakarya. 